\title{
NAT2 Gene
}

National Cancer Institute

\section{Source}

National Cancer Institute. NAT2 Gene. NCI Thesaurus. Code C18311.

This gene plays a role in both the activation and deactivation of xenobiotics. 